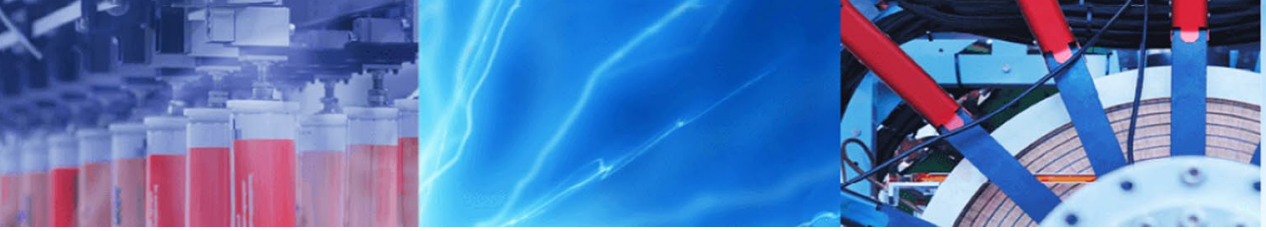

Research Article

\title{
Structure-property relationships of hydrothermally treated western hemlock
}

\author{
Kunlin Song ${ }^{1} \cdot$ Indroneil Ganguly $^{2} \cdot$ Ivan Eastin $^{3} \cdot$ Chang Dou $^{1} \cdot$ Renata Bura ${ }^{1} \cdot$ Anthony Dichiara $^{1}$
}

(c) Springer Nature Switzerland AG 2018

\begin{abstract}
Western hemlock (Tsuga heterophylla), mostly found in west coast of North America, is a highly underutilized and lowvalue timber species, partially because of the presence of wet pockets, which makes wood processing challenging, especially when drying and sawing. The present work studies the modification of western hemlock using a hydrothermal process, which induced significant changes in the chemical structure and physical characteristics of the wood. The treatment caused the degradation of hemicellulose and reduced the quantity of adsorbed water and free hydroxyl groups. As a result, the wood became less hygroscopic and exhibited improved dimensional and thermal stability with a darker and more attractive color. The hydrothermally-induced variations in the wood structure also influenced its mechanical properties. Flexural bending tests revealed that the specific modulus of rupture and specific maximum load decreased after treatment, while the specific modulus of elasticity increased. In addition, the hydrothermal process was successful in eliminating case hardening, which is typically caused by residual compression stress during conventional kiln drying of wood. These results reveal that hydrothermal treatment is a promising method to expand utilization and develop value-added wood products using low quality wood, such as western hemlock.
\end{abstract}

Keywords Hydrothermal treatment $\cdot$ Chemical composition $\cdot$ Hygroscopicity $\cdot$ Dimensional stability $\cdot$ Case hardening

\section{Introduction}

The forestry and wood products manufacturing sectors play an important role in the economy of Washington State in the U.S., particularly in rural, timber-dependent communities [1], providing over 25,000 jobs, generating $\$ 14.5$ billion in gross business revenue and paying over $\$ 1.5$ billion in wages [2]. However, weak domestic demand during the housing crisis was devastating to the forest products industry on the Olympic Peninsula, where the number of sawmills declined by $27.7 \%$ between 2005 and 2014 , while sawmill employment fell by $23.3 \%$, with three more sawmill closures in the past year [3]. Western hemlock is a native wood species of west coast of North America and the volume of hemlock growing on the Olympic Peninsula represents over $40 \%$ of the growing stock [4]. Weak demand has delayed first commercial thinning in young stands, creating an ecological management crisis as stands become so dense that they create wildlife habitat deficits and increase the risk of severe wind and snow damage. When hemlock is not commercially harvestable, ecological options such as managing for other species dependent on early seral openings like neotropical songbirds, ungulates, and insects providing for productive aquatic food chains are no longer available. The poor hemlock market also limits the use of thinningfrom-below management strategies that are needed to speed late seral habitat development. Value-added wood manufacturing can act as a key anchor for both ecological and community well-being in rural areas. Identifying

\footnotetext{
$\triangle$ Anthony Dichiara, abdichia@uw.edu|'School of Environmental and Forest Sciences (SEFS), University of Washington, Seattle, WA, USA. ${ }^{2}$ Center of International Trade in Forest Products (CINTRAFOR), School of Environmental and Forest Sciences (SEFS), University of Washington, Seattle, WA, USA. ${ }^{3}$ School of Environment and Sustainability, University of Michigan, Ann Arbor, MI, USA.
} 
new innovative value-added wood products that could be produced locally from lower valued, underutilized western hemlock would provide an important economic opportunity for rural, timber-dependent communities and support new business opportunities for local entrepreneurs, while contributing to improved forest health and resilience.

The thermal modification of lumber is a relatively new technology in the U.S. that could substantially increase the value of low-quality, underutilized timber species, such as western hemlock $[5,6]$. Thermal modification is usually performed by heating wood with or without steam up to a temperature range of $180-260^{\circ} \mathrm{C}$, which is much more environmentally friendly compared to other wood modification methods such as chemical treatment $[7,8]$. The thermal modification using high-temperature steam, commonly known as hydrothermal treatment, is an increasingly attractive method to improve the quality of wood, due to its more effective heat transfer compared to conventional heat treatment without steam $[7,8]$. This process involves the penetration of steam into the wood, which alters the structure and properties of wood cell wall polymers, resulting in reduced hygroscopicity [9], enhanced dimensional stability [10], increased durability [11], improved color uniformity and stability [12], and increased resistance to natural weathering [13]. Although these studies indicated that hydrothermal treatments affect anatomical characteristics, chemical structure, physical, and mechanical properties of wood, a comprehensive understanding of the structure-property relationships has not been fully elucidated. The hydrothermal method was applied to various hardwood and softwood, such as cedar [14], beech and pine [15], and spruce [16]. However, there are no reports about the hydrothermal modification of western hemlock wood (Tsuga heterophylla), which is particularly relevant considering that conventional kiln drying of hemlock wood is challenging due to the presence of wet pockets. These wet spots induce growth stresses in the wood, which result in excessive product degrade (e.g., warping and twisting) and wood machining issues, such as case hardening [17]. Therefore, it is highly desirable to improve the quality of the underutilized and lowvalue hemlock using hydrothermal treatment, increasing its market by creating value-added wood products and minimizing the negative ecological impacts of delayed commercial thinning.

In the present research, western hemlock wood was hydrothermally modified and changes in its structural, chemical, physical, and mechanical properties were thoroughly investigated. Variations in cell morphology were monitored by optical microscopy, while Fourier transform infrared (FTIR) spectroscopy and high-performance liquid chromatography (HPLC) were employed to track the chemical changes in carbohydrates and lignin in the wood cell walls. The physical properties, including density, porosity, hygroscopicity, wettability dimensional stability, and thermal stability of the kiln dried wood (KW) and hydrothermally modified wood (TW) were analyzed. Flexural tests and case hardening measurements were conducted to examine the mechanical properties of the wood before and after hydrothermal modification. Finally, the structure-property relationships were discussed along with possible mechanisms for the hydrothermal treatment.

\section{Materials and methods}

\subsection{Materials}

Western hemlock lumber was donated by the Interfor sawmill located in Port Angeles, WA, USA. Twenty-four lumbers of $2438 \times 85 \times 35 \mathrm{~mm}$ were randomly selected and kiln dried to an average moisture content of $12.0 \% \pm 0.5 \%$ prior to thermal treatment and testing. All test specimens were straight (i.e., contained no crook, twist or bow) with minimal slope of grain, and had no wane.

\subsection{Thermal treatment}

Each western hemlock lumber was cut into two matching test specimens of identical dimensions (Fig. 1). One piece of the matching lumber specimens was designated as the kiln-dried KW sample, while the second matching specimen was designated as the thermally-modified TW sample. The TW specimens were loaded into a hydrothermal reactor and treated based on the conditions listed in Table 1. The treatment conditions, including parameters like temperature, time and pressure, were based on previous research conducted in the Natural Resources Research Institute at the University of Minnesota in Duluth (UMDNRRI) $[7,16]$. Upon completion of the process, the samples were conditioned in a standard environment with steam to

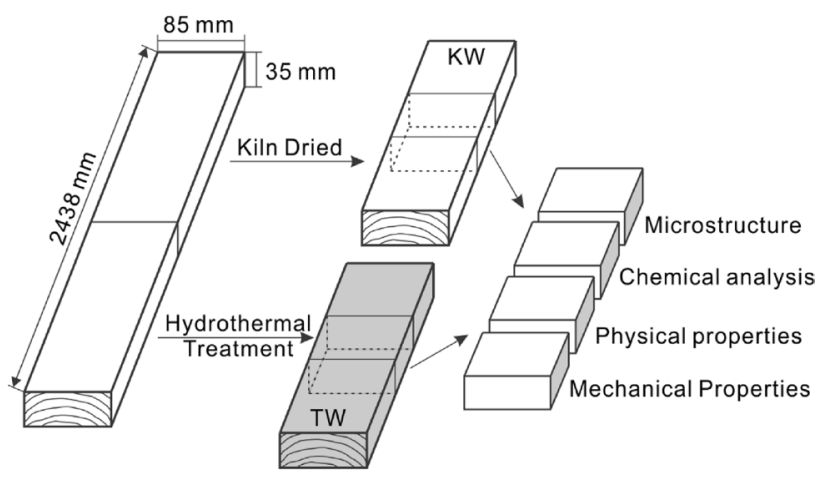

Fig. 1 Schematic picture showing hydrothermal treatment and sample preparation for characterization 
Table 1 Treatment conditions for the thermal modification process

\begin{tabular}{lccll}
\hline Step & $\begin{array}{l}\text { Temperature } \\
\left({ }^{\circ} \mathrm{C}\right)\end{array}$ & $\begin{array}{l}\text { Treatment } \\
\text { time }(\mathrm{min})\end{array}$ & $\begin{array}{l}\text { Pressure (abso- } \\
\text { lute bar) }\end{array}$ & $\begin{array}{l}\text { Spray } \\
\text { time }(\mathrm{s})\end{array}$ \\
\hline 1 & 80 & 10 & 1.5 & 0 \\
2 & 100 & 110 & 1.5 & 0 \\
3 & 120 & 110 & 1.5 & 0 \\
4 & 140 & 110 & 1.5 & 0 \\
5 & 170 & 110 & 1.5 & 0 \\
6 & 140 & 110 & 3.4 & 5 \\
7 & 120 & 110 & 1.8 & 5 \\
8 & 110 & 110 & 1 & 5 \\
\hline
\end{tabular}

a moisture content of $4.5 \%$ prior to structure and property characterization.

\subsection{Characterization}

A Zeiss Axiocam ERc5s digital camera mounted on a Zeiss Axiolab light microscope was used to examine the morphology of the wood before and after treatment. Wood blocks $(1 \times 1 \times 5 \mathrm{~mm})$ were cut from matching $\mathrm{KW}$ and TW specimens in the middle of same growth rings. The samples were dehydrated in graded acetone $(70 \%, 90 \%$, and $100 \%)$ and embedded in epoxy resin. Transverse sections with a thickness of $5 \mu \mathrm{m}$ were prepared with a Leica ultramicrotome. The cell wall thickness and lumen diameter of at least 50 randomly selected wood cells were measured and computed using ImageJ software.

Chemical changes in the wood structure were monitored using a Shimadzu FTIR with ATR mode (IRPrestige-21, Shimadzu Corp., Kyoto, Japan). All spectra were collected within the wavenumber range of $750-4000 \mathrm{~cm}^{-1}$ at a spectral resolution of $4 \mathrm{~cm}^{-1}$. The elemental composition of both KW and TW samples was measured by a PerkinElmer elemental analyzer (2400 Series II system) and the oxygen content was calculated by difference.

The chemical composition of the KW and TW samples was determined based on a previously established procedure [18]. The carbohydrate and lignin contents were analyzed according to a modified method derived from TAPPI Standard Method T-222 om-98 [19]. Briefly, $0.2 \mathrm{~g}$ finely ground sample was subjected to $3 \mathrm{ml} 72 \% \mathrm{H}_{2} \mathrm{SO}_{4}$ for $2 \mathrm{~h}$ at room temperature, then diluted into $120 \mathrm{ml}$ total volume and autoclaved at $121^{\circ} \mathrm{C}$ for $1 \mathrm{~h}$. The samples, after two-step acid hydrolysis, were filtered through sintered-glass crucibles. The acid insoluble lignin content was determined gravimetrically by measuring the mass of oven-dried crucibles before and after filtration. The acid soluble lignin was measured at absorbance reading of $205 \mathrm{~nm}$ using a UV/Vis spectrophotometer (UV-1700, Shimadzu, Japan). The lignin reported in this study comprised both the acid insoluble lignin and the acid soluble lignin. Carbohydrate composition of the filtrate is analyzed by HPLC (ICS-3000, Sunnyvale, CA, USA) following a previously established procedure [20]. Ash content of samples was measured gravimetrically by heating 20 -mesh-milled dry biomass to $600{ }^{\circ} \mathrm{C}$ for $18 \mathrm{~h}$ [21]. Extractives content was determined by the a two-step water/ethanol extraction methods following the National Renewable Energy Laboratory (NREL) protocols [22].

The density, porosity, moisture content, water absorption, and swelling of the KW and TW were measured to investigate the physical change of wood subjected to the thermal treatment. The air-dried mass $\left(M_{a d}, g\right)$ and volume $\left(V_{\mathrm{ad}}, \mathrm{cm}^{3}\right)$ were recorded after the KW and TW samples were conditioned in a controlled atmosphere for at least $48 \mathrm{~h}\left(50 \%\right.$ relative humidity, $\left.20^{\circ} \mathrm{C}\right)$. Subsequently, the samples were dried in an oven at $103 \pm 2{ }^{\circ} \mathrm{C}$ until no appreciable change $(\leq 0.001 \mathrm{~g})$ in sample mass was observed to measure the oven-dried mass $\left(M_{o d}, g\right)$ and volume $\left(V_{\text {od }}\right.$ $\left.\mathrm{cm}^{3}\right)$. Then, the oven-dried density $\left(\rho_{\text {od }}, \mathrm{g} / \mathrm{cm}^{3}\right)$, porosity $(P, \%)$, moisture content $\left(M_{C^{\prime}} \%\right)$, water absorption $\left(W_{a}, \%\right)$, volumetric swelling $\left(\mathrm{S}_{\mathrm{v}}, \%\right)$, tangential swelling $\left(\mathrm{S}_{\mathrm{T}}, \%\right)$, radial swelling $\left(S_{R}, \%\right)$, and longitudinal swelling $\left(S_{L}, \%\right)$ were calculated according to the following equations:

$\rho_{\text {od }}=M_{\text {od }} / V_{\text {od }}$

$P=100 \times\left(1-\rho_{\text {od }} / \rho_{\text {ow }}\right)$

$M_{c}=100 \times\left(M_{a d}-M_{o d}\right) / M_{o d}$

$\mathrm{W}_{\mathrm{a}}=100 \times\left(\mathrm{M}_{\mathrm{w}}-\mathrm{M}_{\mathrm{od}}\right) / \mathrm{M}_{\mathrm{od}}$

$S=100 \times\left(X_{w}-X_{o d}\right) / X_{o d}$

where $\rho_{\text {ow' }} M_{w}, X_{w^{\prime}} X_{o d}$, and $S$ were cell wall density ( $g$ / $\left.\mathrm{cm}^{3}\right)$, mass $(\mathrm{g})$ of water saturated wood, volume $\left(\mathrm{cm}^{3}\right)$ or dimensions $(\mathrm{cm})$ of water saturated wood, volume $\left(\mathrm{cm}^{3}\right)$ or dimensions $(\mathrm{cm})$ of oven-dried wood, and volumetric or dimensional change (\%), respectively. The $\rho_{\text {ow }}$ was arbitrarily chosen as $1.52 \mathrm{~g} / \mathrm{cm}^{3}$ within the range of $1.517-1.529 \mathrm{~g} /$ $\mathrm{cm}^{3}$ for softwood [23]. The $M_{w}$ and $X_{w}$ were obtained by immersing the samples in a water bath at room temperature and weighing them until equilibrium was declared.

Thermal stability of the KW and TW was investigated using a thermogravimetric analyzer (TGA $60 \mathrm{AH}, \mathrm{SHI}-$ MADZU Instrument, Japan). Each sample of $10 \mathrm{mg}$ was heated from room temperature to $800^{\circ} \mathrm{C}$ at a rate of $10^{\circ} \mathrm{C} /$ min under nitrogen $(50 \mathrm{~mL} / \mathrm{min})$. The equilibrium moisture contents (EMC) of the wood at varied relative humidity within $0-90 \%$ were determined at $20^{\circ} \mathrm{C}$. The samples were weighed until they reached equilibrium at each relative humidity level and the EMC of each sample was calculated according to ISO 13061-1 [24]. 
The surface wettability of the wood before and after thermal treatment was tested using a FTA 200 contact angle analyzer (First Ten Ångstroms Inc., Portsmouth, VA, USA). Droplets of deionized water were dispensed onto the surface of each specimen using a microsyringe. The image of the drop was immediately captured after contact with the wood and the contact angle was determined using the tangent method. Furthermore, the size and shape of the drops changed over time due to water absorption in the wood. This dynamic process was recorded by capturing images of the droplets every $0.2 \mathrm{~s}$ for KW and every $5 \mathrm{~s}$ for TW until contact angles lower than $5^{\circ}$ were measured.

The color change of the wood after thermal treatment was measured using a colorimeter (Jinan Cyeeyo Instrument Co., Ltd., Jinan, China). The color was assessed based on the CIE $\mathrm{L}^{*} \mathrm{a}^{*} \mathrm{~b}^{*}$ color space method. The three color coordinates $L^{*}, a^{*}$, and $b^{*}$ were recorded for both $\mathrm{KW}$ and TW, and the color saturation $\left(C^{*}\right)$ and total color difference $\left(\Delta \mathrm{E}^{*}\right)$ were calculated as follows:

$C^{*}=\sqrt{a^{* 2}+b^{* 2}}$

$\Delta E^{*}=\sqrt{\left(\Delta L^{*}\right)^{2}+\left(\Delta a^{*}\right)^{2}+\left(\Delta b^{*}\right)^{2}}$

The mechanical properties of KW and TW test specimens in structural sizes were evaluated according to ASTM D198. The samples were cut to the full width and thickness of the lumber with the length being set so that a 16-1 span-to-depth ratio was achieved for flexural testing in the flatwise direction. For statistical soundness, 24 specimens of each type of wood (i.e. KW and TW) were tested. Threepoint bending to failure was performed using a 30-kip screw driven universal testing machine equipped with a 10-kip load cell and LVDT deflectometer. Load and deflection data were collected and recorded in real time and the flexural properties (i.e., MOE and MOR) were computed as per the ASTM D198 standard. The specific flexural properties were also reported by normalizing by the material density. Since each western hemlock lumber was cut into two matching specimens, as described earlier, this resulted in a natural paring of each of the KW samples to their respective TW counterparts. Therefore, a pairwise $t$ test was conducted for identifying the changes in mechanical properties as a result of thermal modification. Moreover, to investigate the influence that the presence of defects (i.e., knots) may have on the mechanical properties, a pairwise $t$ test analysis was performed on samples with and without defects.

To evaluate the effectiveness of thermal modification in relieving case hardening, paired samples of KW and TW with various grain orientations were tested. Matching KW and TW samples were prepared with sections that were parallel to the wood grain (tangential orientation), perpendicular to the wood grain (radial orientation) and across the wood grain at a specific angle. The testing consisted of cutting the test specimens three-quarters of the way through the width of the wood blocks using a circular saw. The width of the cut was then measured at the top of the cut (i.e. located in the interior area of the sample) and at the bottom of the cut (i.e. located on the outer edge of the sample). If casehardening were present, the compression stresses would cause the wood to compress inwards resulting in a smaller width of cut at the bottom of the sample.

\section{Results and discussion}

\subsection{Microstructure observations}

Hydrothermal treatment can induce various changes in the wood microstructure depending on the conditions, such as processing time and temperature. The cell lumen dimensions of pine wood was reduced significantly after thermal modification [25], which was attributed to the collapse of wood cell wall pores upon treatment. After thermal modification, the pores remained permanently closed, decreasing the cell lumen dimensions and preventing the wood to swell even when exposed to moisture [7, 25]. At higher temperatures (i.e. $>200^{\circ} \mathrm{C}$ ), however, the cell lumen dimensions increased because of the decomposition of cell wall components [25]. Similarly, the destruction of tracheid walls and ray cells and cell wall delamination/distortion were observed for thermally modified cedar wood at $220^{\circ} \mathrm{C}[9,14]$. In the present work, the structural integrity of the wood cell walls was maintained without significant morphological changes, as demonstrated by dark field optical microscopy. Figure 2 shows that the tangential cell lumen diameter was $35 \pm 6 \mu \mathrm{m}$ and $34 \pm 5 \mu \mathrm{m}$, and the cell wall thickness was $5.4 \pm 1.1 \mu \mathrm{m}$ and $5.2 \pm 1.0 \mu \mathrm{m}$ for the KW and TW, respectively. The minimal morphological changes observed after hydrothermal treatment can be attributed to the relatively low temperature of the process (i.e. $170^{\circ} \mathrm{C}$ ).

\subsection{Chemical compositions}

Monitoring chemical changes in the wood is critical to understand the variations in its physical and mechanical properties after treatment. Water and volatile extractives are lost first as the wood is gradually heated, followed by the decomposition of cell wall macromolecules typically at temperatures above $170^{\circ} \mathrm{C}$, with hemicelluloses being the most thermal-chemically sensitive component of wood [7, 26]. The FTIR spectra of the TW specimens (Fig. 3) are characterized by a reduction in absorption intensity at 1654 

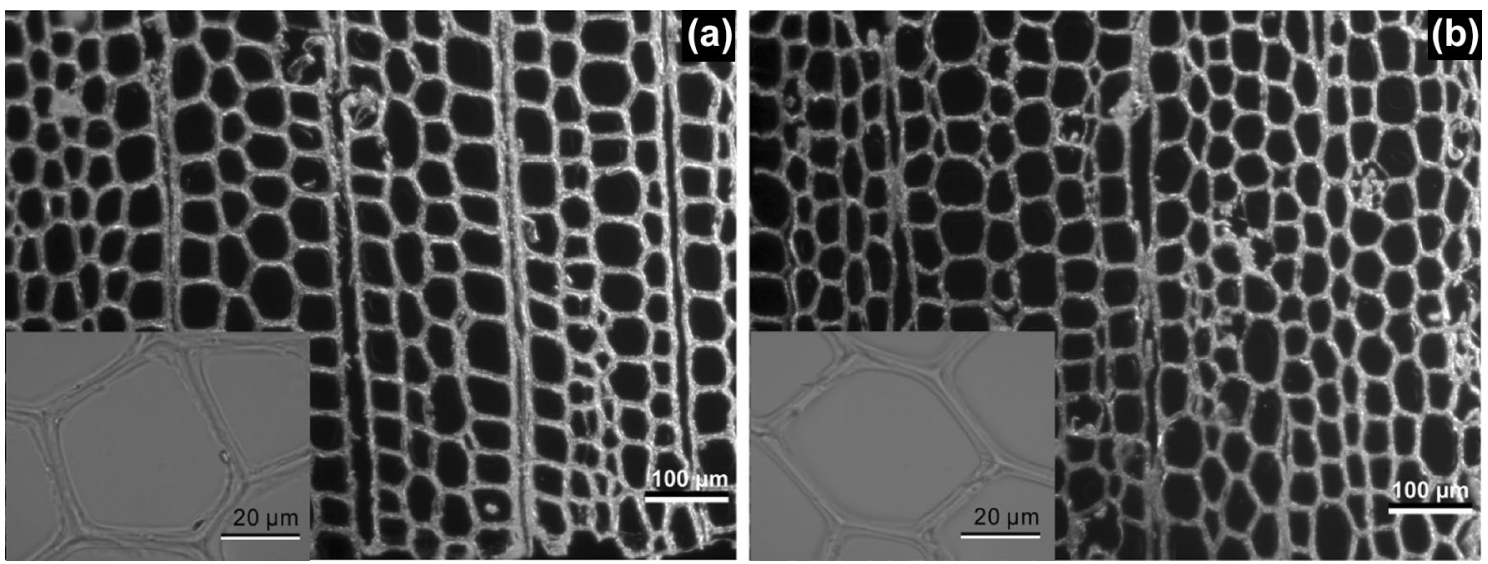

Fig. 2 Dark field microscopy images of representative transverse sections of matching KW (a) and TW (b) samples taken from the middle of the same growth ring. High magnification bright field microscopy images are shown in the insets

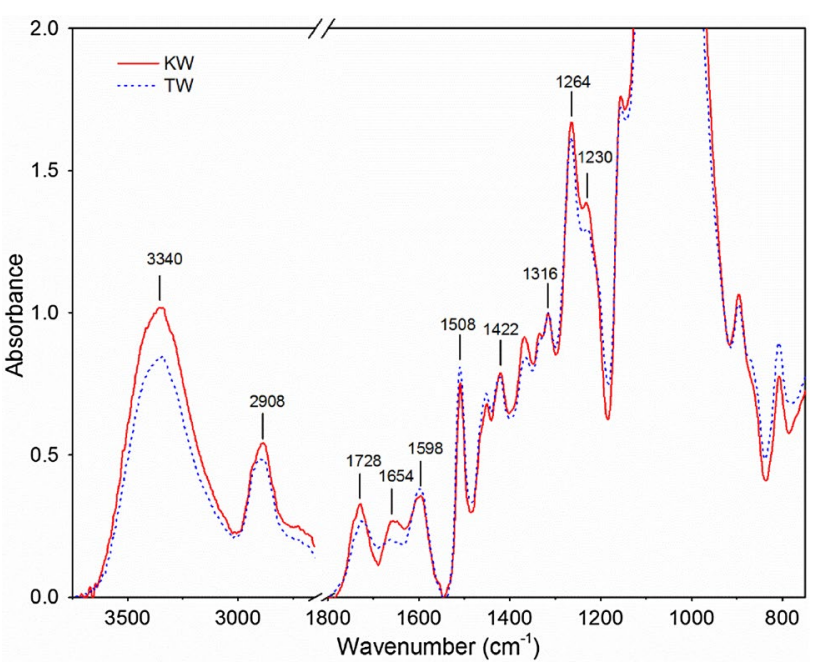

Fig. 3 FTIR spectra of the wood before and after hydrothermal treatment

and $3340 \mathrm{~cm}^{-1}$, assigned to adsorbed water and hydroxyl groups, respectively [27]. In addition, the decrease of the absorption peaks after thermal treatment at $1728 \mathrm{~cm}^{-1}$ $(\mathrm{C}=\mathrm{O}$ stretching in the $\mathrm{O}=\mathrm{C}-\mathrm{OH}$ group of glucuronic acid unit) and $1230 \mathrm{~cm}^{-1}$ (C-O stretching in the $\mathrm{O}=\mathrm{C}-\mathrm{O}$ group of xylan) reveal the partial degradation of hemicelluloses, which is consistent with previous findings [28]. It appeared that cellulose and lignin were nearly not affected by the thermal treatment, as no significant differences were observed between the FTIR spectra of KW and TW at the characteristic absorption bands of cellulose (i.e. $\mathrm{CH}_{2}$ scissoring at $1422 \mathrm{~cm}^{-1}$ and $\mathrm{CH}_{2}$ wagging at $1316 \mathrm{~cm}^{-1}$ ) and lignin (i.e. aromatic skeletal vibration plus $\mathrm{C}=\mathrm{O}$ stretching at $1598 \mathrm{~cm}^{-1}$, aromatic skeletal vibration at $1508 \mathrm{~cm}^{-1}$, and vibration of guaiacyl ring plus $\mathrm{C}=\mathrm{O}$ stretching at $1264 \mathrm{~cm}^{-1}$ ) [29].
Table 2 The chemical composition and physical characteristics of the wood before and after hydrothermal treatment

\begin{tabular}{lcr}
\hline & \multicolumn{1}{l}{ KW } & \multicolumn{1}{l}{ TW } \\
\hline Chemical composition (\%) & & \\
Mannan & $12.76 \pm 0.33$ & $11.45 \pm 0.81$ \\
Xylan & $4.50 \pm 0.12$ & $3.60 \pm 0.19$ \\
Galactan & $1.81 \pm 0.07$ & $0.92 \pm 0.04$ \\
Arabinan & $0.93 \pm 0.02$ & $0.10 \pm 0.02$ \\
Glucan & $50.27 \pm 0.54$ & $52.58 \pm 1.30$ \\
Lignin & $29.57 \pm 1.68$ & $33.81 \pm 0.85$ \\
Extractives & $1.56 \pm 0.15$ & $5.26 \pm 0.70$ \\
Ash & $0.16 \pm 0.06$ & $0.13 \pm 0.03$ \\
Organic fraction element (\%) & & \\
C & $49.66 \pm 0.25$ & $52.03 \pm 0.18$ \\
H & $7.26 \pm 0.51$ & $7.31 \pm 0.02$ \\
O & $42.92 \pm 0.74$ & $40.53 \pm 0.20$ \\
Air-dried density $\left(\mathrm{g} / \mathrm{cm}^{3}\right)$ & $0.38 \pm 0.02$ & $0.36 \pm 0.02$ \\
Oven-dried density $\left(\mathrm{g} / \mathrm{cm}^{3}\right)$ & $0.36 \pm 0.03$ & $0.35 \pm 0.02$ \\
Porosity (\%) & $76 \pm 2$ & $77 \pm 1$ \\
Water absorption $(\%)$ & $67.2 \pm 8.5$ & $41.7 \pm 3.9$ \\
Moisture content $(\%)$ & $12.1 \pm 0.3$ & $7.4 \pm 0.6$ \\
\hline
\end{tabular}

The quantitative changes in carbohydrates, lignin, and extractives after the hydrothermal treatment are listed in Table 2. The HPLC analysis indicated that the hydrothermal treatment reduced the contents of arabinose, galactose, xylose and mannose by $89 \%, 50 \%, 20 \%$ and $10 \%$, respectively, while the level of glucan increased slightly. These results confirmed the degradation of hemicellulose observed by FTIR spectroscopy and were consistent with previous studies [30,31]. Since glucan mostly originates from cellulose, which accounted for more than $40 \%$ of the wood cell wall components [32], the partial loss of hemicellulose and almost unaltered structure of cellulose and 
lignin can explain the rise of glucan after hydrothermal treatment. Noteworthy, the decrease in total sugar content in the TW is expected to improve decay resistance and durability against rot and insect attack [33]. Meanwhile, the small molecular weight products, such as organic acids, generated from the hemicellulose degradation can be extracted using hot water and ethanol [33], increasing the extractive content from 1.56 to $5.26 \%$ after hydrothermal treatment. Moreover, elemental analysis revealed that TW samples exhibited higher carbon content and lower oxygen content than KW specimens (Table 2).

\subsection{Physical properties}

The physical properties of the wood were strongly affected by the hydrothermal treatment. After processing, the wood dimensions slightly decreased along the width ( $1.1 \%$ reduction) and depth ( $1.5 \%$ reduction). Although these values are relatively small, they are statistically significant across all the specimens tested. The density of the wood was also reduced after hydrothermal treatment. The $\mathrm{KW}$ had a $\rho_{\text {ad }}$ of $0.38 \mathrm{~g} / \mathrm{cm}^{3}$ and a $\rho_{\text {od }}$ of $0.36 \mathrm{~g} / \mathrm{cm}^{3}$, while the TW exhibited a $\rho_{\text {ad }}$ of $0.36 \mathrm{~g} / \mathrm{cm}^{3}$ and a $\rho_{\text {od }}$ of $0.35 \mathrm{~g} /$ $\mathrm{cm}^{3}$ (Table 2). The decrease in wood density was mainly attributed to the loss of bound water, the degradation of hemicelluloses into volatile products, and the evaporation of extractives. These results are consistent with previous research reporting greater diminution in wood density at higher temperatures $\left(220^{\circ} \mathrm{C}\right)$ [14]. Furthermore, the removal of wood cell wall macromolecules during hydrothermal treatment can generate new pores in the cell walls [7], which may explain the slight increase in porosity from $76 \%$ for KW to $77 \%$ for TW.

The hygroscopic nature of the wood was markedly reduced after hydrothermal treatment. Compared to the
$\mathrm{KW}$, the water sorption of TW was reduced by $38 \%$ and its moisture content at air-dried condition decreased by 39\% (Table 2). The equilibrium moisture content (EMC) was also investigated at different relative humidity, as presented in Fig. 4a. The TW absorbed less moisture than KW, especially at higher relative humidity, which is consistent with previous studies $[26,28]$. Water sorption in wood is closely related to the availability and accessibility of free hydroxyl groups. The degradation of hemicelluloses during hydrothermal treatment (Table 1) induced a reduction of the total amount of hydroxyl groups, including the free hydroxyl groups [34-36]. In addition, the relative proportion of crystalline cellulose is typically higher in TW than in $\mathrm{KW}$, which might hinder the accessibility of free hydroxyl groups to water. Since wood is known to swell in contact with water, the decreased water sorption of the TW was expected to have reduced dimensional changes compared to the KW. As shown in Fig. 4b, after immersion in water, the TW had substantially lower $S_{T}$ and $S_{R}$ with a slight decrease in $S_{L}$, resulting in a $67 \%$ reduction in $S_{V}$, compared to $\mathrm{KW}$. The variations in swelling along the different direction $\left(S_{T}, S_{R}, S_{L}\right)$ can be attributed to the anisotropic nature of wood. These observations were consistent with previous studies [37, 38]. Furthermore, the above-mentioned decrease in hydroxyl groups is expected to change the surface wettability of wood. The wettability of KW and TW was evaluated by measuring water contact angles, as illustrated in Fig. 5. The initial water contact angle of KW was $52^{\circ}$ (Fig. $5 \mathrm{a}$ ), and increased to $85^{\circ}$ after hydrothermal treatment (Fig. 5b), which was consistent with the previous study [39]. The water contact angle of KW exhibited a fast decrease over time and complete wetting was achieved in less than $25 \mathrm{~s}$. In contrast, the water contact of angle of TW diminished at a much slower rate and complete wetting took approximately 2000 s. Note that the effect
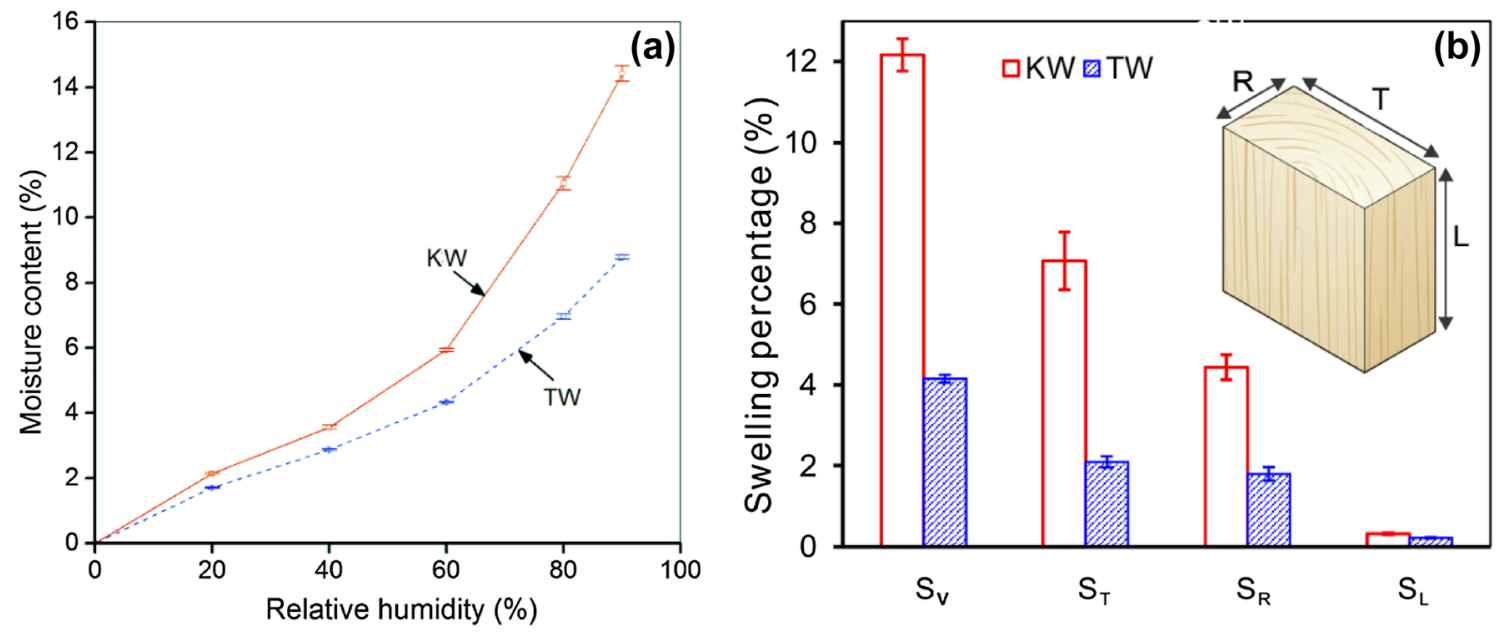

Fig. 4 The moisture sorption isotherms (a) and swelling percentage (b) of the KW and TW 

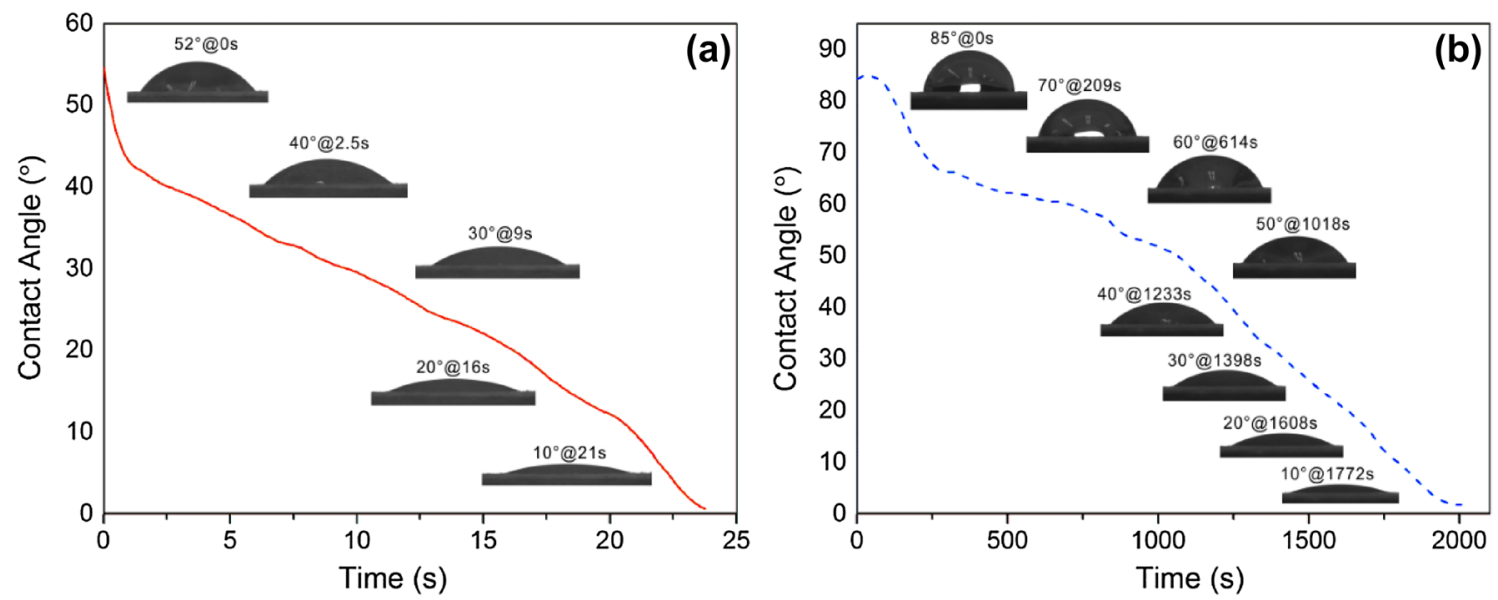

Fig. 5 Evolution of water contact angle over time for the KW (a) and TW (b)

of water evaporation was not considered here. In summary, the reduced hygroscopicity, decreased hydrophilicity, and improved dimensional stability of the wood after hydrothermal treatment was attributed to the decrease in bound water and free hydroxyl groups.

\subsection{Thermal stability}

The thermal degradation of the KW and TW was analyzed, as shown in Fig. 6. A distinct peak in the differential thermogravimetric (DTG) curves (Fig. 6b), attributed to the decomposition of cellulose, was observed with a "shoulder" (square) that can be ascribed to hemicellulose degradation under inert atmosphere, which typically overlap with the main cellulose peak [40]. The high-temperature "tails" were commonly attributed to the thermal degradation of lignin [40]. In comparison, the thermogravimetric
(TG) curve of the wood shifted to higher temperature after the thermal treatment (Fig. 5a), and the DTG peak temperature increased from $383^{\circ} \mathrm{C}(\mathrm{KW})$ to $386^{\circ} \mathrm{C}$ (TW), indicating that the wood thermal stability was improved to some extent by the hydrothermal treatment. In addition, the "shoulder" in the DTG curve of TW was weaker compared to KW, confirming the partial loss of hemicellulose after hydrothermal processing. Furthermore, the elimination of volatile organic compounds and small degradation of hemicellulose subject to thermal treatment resulted in the increased residue weight from $20 \mathrm{wt} \%$ (KW) to $22 \mathrm{wt} \%$ (TW).

\subsection{Appearances}

The hydrothermal treatment of wood visibly changed its surface color, as illustrated in Fig. 7 and characterized by
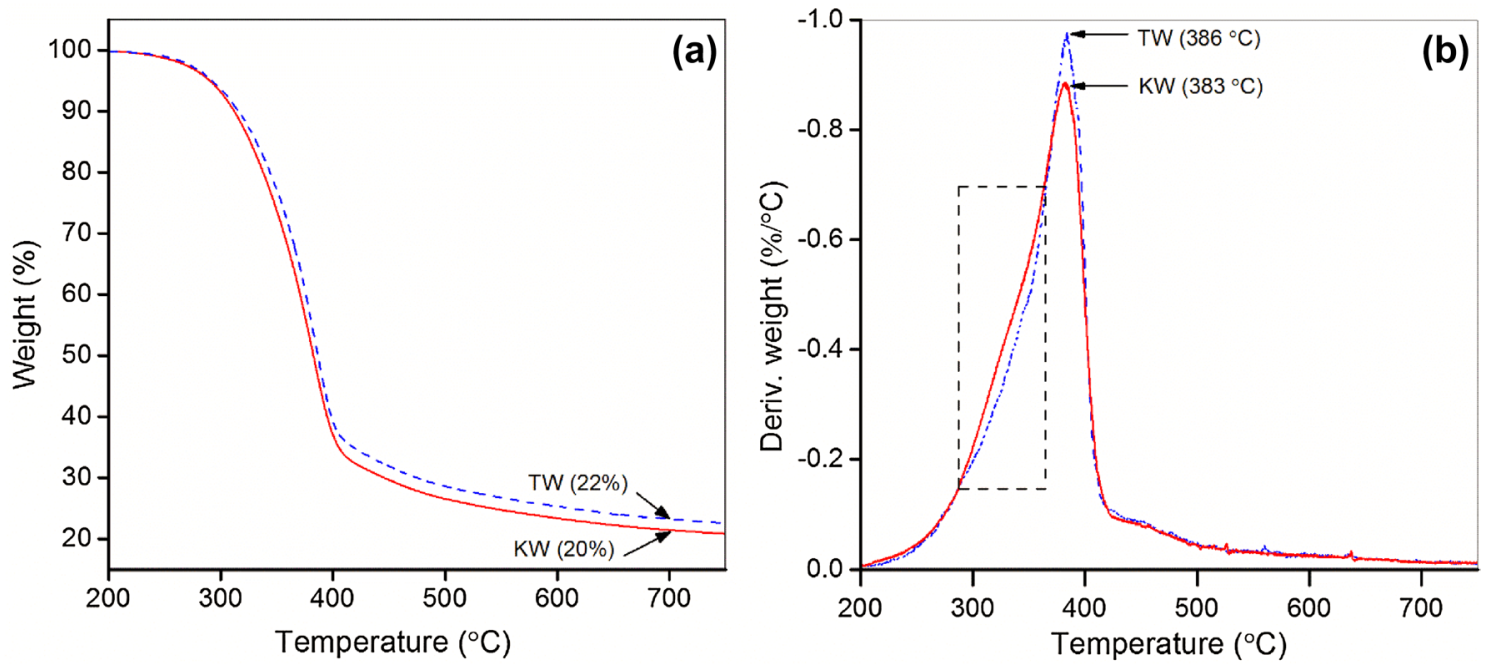

Fig. 6 The TG (a) and DTG (b) curves of the wood before and after hydrothermal treatment 
Fig. 7 The appearance characteristics of western hemlock before and after hydrothermal treatment at $170{ }^{\circ} \mathrm{C}$ (a). Photographs of laser-engraved KW (b) and TW (c)
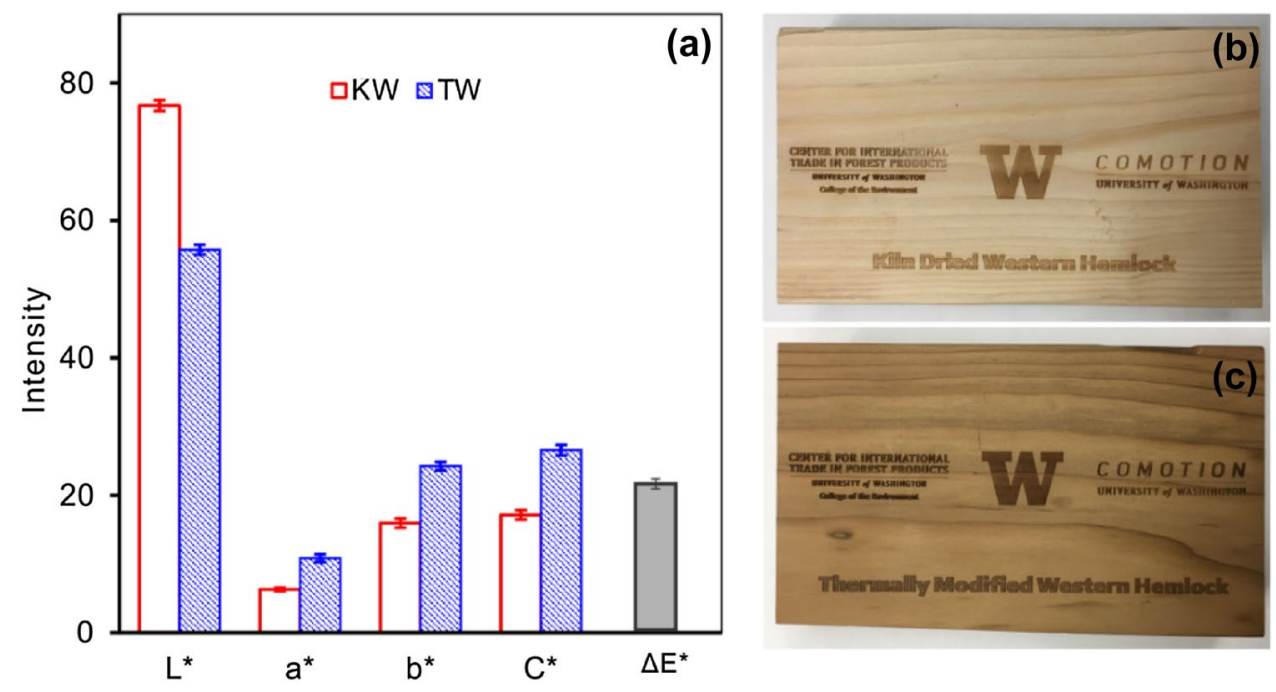

the large $\Delta \mathrm{E}^{*}$. The TW exhibited lower $\mathrm{L}^{*}$ and higher $\mathrm{a}^{*}, \mathrm{~b}^{*}$, and $\mathrm{C}^{*}$ compared to the KW. The reduced lightness and marked color differences are consistent with previous studies [41, 42], and might be caused by the presence of low molecular weight lignin fragments with high reactivity generated from the cleavage of bonds between lignin and hemicelluloses due to the hemicellulose degradation, which promotes darkening reactions $[38,41]$. The color change was reported to strongly depend on treatment conditions, such as temperature, time, and steam pressure [43], which could be tailored to produce woods with various color shades to meet the versatile favors and needs. The darker and warmer wood obtained after hydrothermal treatment are often more appealing for decorative enduse applications (Fig. 7c). In addition, it was found that the color stability of hydrothermally treated wood (ash, beech, pine, and poplar) was greatly improved with minimal changes observed after exposure to UV for $835 \mathrm{~h}$ [12]. No differences in $L^{*}, a^{*}, b^{*}$, and $C^{*}$ values were observed for the TW exposed to ambient daylight for $72 \mathrm{~h}$. This can prevent the use of toxic coatings and paintings for coloring and resistance to photo-degradation.

\subsection{Mechanical properties}

Flexural tests were conducted to analyze the strength characteristics of KW and TW. The results, summarized in Fig. 8, revealed that the mechanical properties changed significantly as a result of the hydrothermal modification process, with MOR and ML being the most impacted. After hydrothermal treatment, the MOR was decreased by $35 \%$ and the ML diminished by $38 \%$, which is consistent with previous work on spruce [16]. While the magnitude of the reduction in MOR and ML values after hydrothermal treatments depends on wood species, larger reductions were found at higher temperatures and longer processing times. In contrast, the hydrothermal modification process improved the MOE of western hemlock by $6.4 \%$, which is consistent with a previous study reporting a $5 \%$ increased in MOE after hydrothermal treatment of wild pear at $160^{\circ} \mathrm{C}$ for $2 \mathrm{~h}$ [38]. This indicates that the TW hemlock specimens are stiffer than their corresponding KW counterparts. Furthermore, statistical analysis revealed that the presence of defects had a negligible influence on the mechanical properties of TW. To evaluate the effect of density, which was found to change with hydrothermal treatment (Table 2), on the strength characteristics of wood, the specific mechanical properties (i.e. S-MOR, S-ML, or S-MOE) were determined by dividing the MOR, ML, and MOE values by the specific gravity. After hydrothermal treatment, the S-MOR and S-ML decreased by $31 \%$ and $34 \%$, respectively, while the S-MOE increased by $13.7 \%$ (Fig. 8a), indicating that the variations in wood density cannot solely explain the changes in mechanical characteristics. Other aspects, such as differences in chemical structure before and after hydrothermal treatment must be considered. In the cell walls of softwood (i.e. western hemlock), the cellulose fibers act as reinforcing fillers in a matrix of lignin and hemicellulose with a similar organization than that of fiber-reinforced polymer composites [44-46]. The integrity of the interactions among the cellulose, lignin, and hemicellulose (i.e. hydrogen and covalent bondings) endowed wood with excellent strength and flexibility $[26,47]$. The degradation of hemicellulose in the TW weakened these interactions, while the stiff lignin and cellulose were kept almost intact, hence decreasing the wood flexibility MOR and $\mathrm{ML}$ and making it more brittle.

In addition, it was found that the hydrothermal treatment was effective in eliminating case hardening in kiln dried western hemlock lumber. The presence of wet 

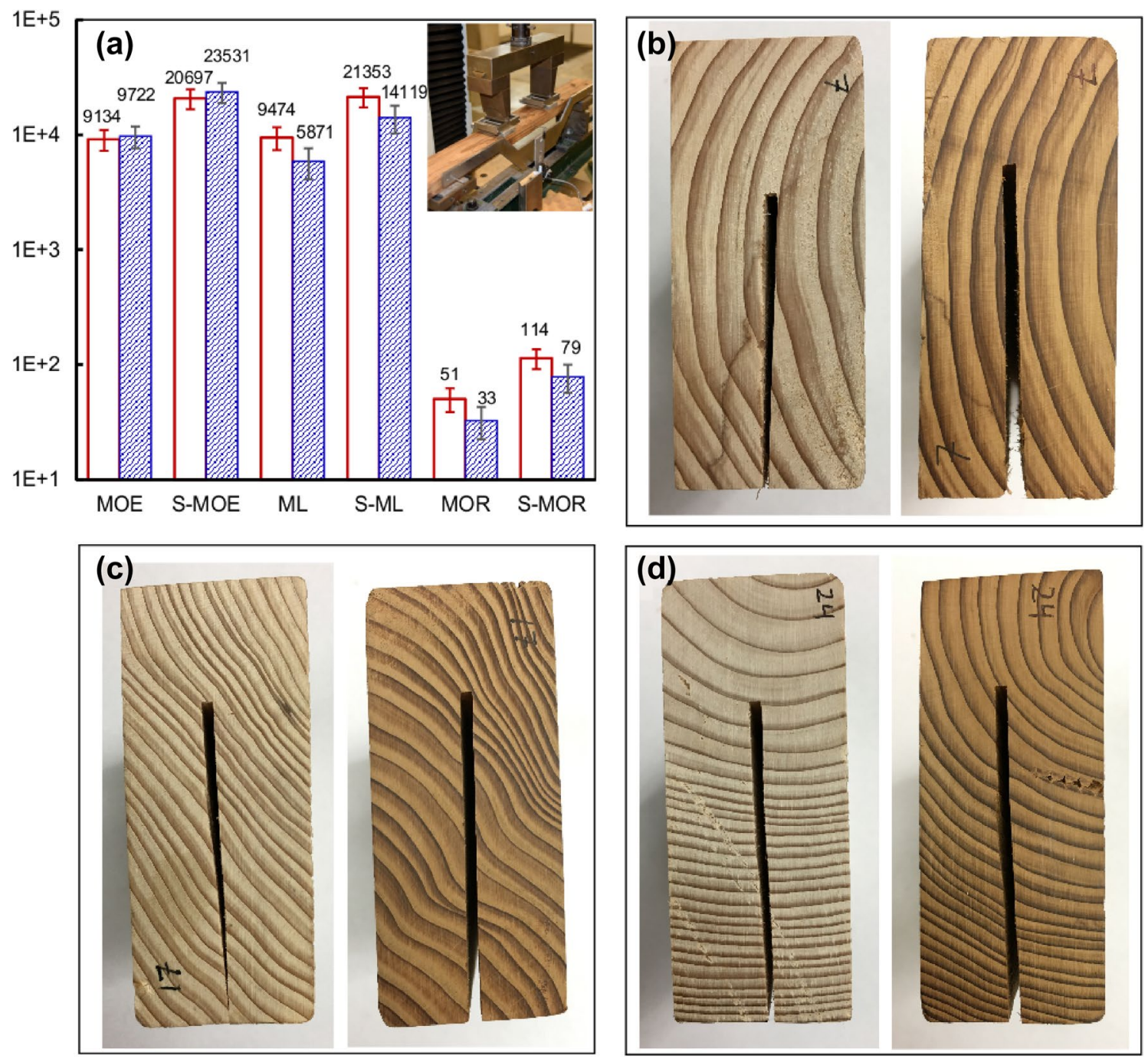

Fig. 8 a Histogram of the mechanical properties (MOE and MOR in $\mathrm{MPa}, \mathrm{ML}$ in N) of KW and TW with a photo of the bending test in the inset. $\mathbf{b}-\mathbf{d}$ Pictures showing the case hardening along different direction (b: Tangential; c: Cross grain; $\mathbf{d}$ : Radial) of the wood before and after hydrothermal treatment

thermal modification in relieving case hardening, paired samples of KW and TW were tested. The results of the casehardening tests are summarized in Table 3. Case hardening was observed in all KW samples of western hemlock regardless of grain orientation, as illustrated in Fig. $8 \mathrm{~b}-\mathrm{d}$. The degree to which the cut width was reduced in the case hardened samples ranged from 24.5 to $41.4 \%$. More importantly, the KW pinched against the saw blade while they were being cut, acting as a brake slowing the rotation of the saw blade and causing it to twist and pull, which might damage the equipment. In contrast, the cut width increased by $3.2-54.7 \%$ in all TW samples and there was no blade pinching during cutting along all grain orientation. These observations reveal that hydrothermal treatment is effective in relieving case hardening in western hemlock lumber. 
Table 3 Results of the casehardening test

\begin{tabular}{llllll}
\hline Sample & Cut angle & $\begin{array}{l}\text { Interior width } \\
(\mathrm{mm})\end{array}$ & $\begin{array}{l}\text { Exterior width } \\
(\mathrm{mm})\end{array}$ & Change (\%) & Observation \\
\hline KW & Tangential & 2.49 & 1.57 & -36.73 & Casehardened \\
KW & Cross grain & 2.44 & 3.77 & -41.40 & Casehardened \\
KW & Radial & 2.36 & 1.38 & -24.48 & Casehardened \\
TW & Tangential & 2.44 & 3.06 & 54.69 & No casehardening \\
TW & Cross grain & 2.44 & 1.84 & 25.52 & No casehardening \\
TW & Radial & 2.41 & 2.49 & 3.16 & No casehardening \\
\hline
\end{tabular}

\section{Conclusion}

The hydrothermal treatment significantly modified the chemical composition, physical and mechanical properties of the western hemlock wood. The thermal modification caused the loss of extractives and adsorbed water and the decomposition of hemicellulose in the wood. It became less hydrophilic, more dimensionally and thermally stable, and darker in color after hydrothermal modification. The decrease in MOR and ML and increase in MOE of wood after hydrothermal treatment may limit the end use application of the thermally modified wood. However, the relative benefit of an evenly low hygroscopicity and reduction/elimination in case hardening addresses one of the most problematic aspect of species under consideration. One of the most desired aspects of wood used for furniture manufacture is its re-sawing capability. An even moisture content and reduced case hardening makes the wood structurally stable (less warping and twisting) after re-sawing. The low hygroscopicity, high dimensional stability, darker color, and eliminated case hardening of the wood makes it a suitable engineered wood product for most outdoor and indoor applications.

Acknowledgements The authors would like to thank the following individuals and groups for their support of this research. Steve Courtney and John Thomas of Interfor Corporation who donated the western hemlock lumber, Matt Aro with the Natural Resources Research Institute at the University of Minnesota-Duluth who thermally modified the western hemlock samples, Robert Duncan with the Composite Materials and Engineering Lab at Washington State University who conducted the mechanical testing of the thermally modified samples, and Dr. John C. Berg, Dr. Igor Novosselov and Devin Chandler at the University of Washington in Seattle for their assistance with water contact angle measurement, EMC test, and elemental analysis, respectively. The authors would also like to express their appreciation to Jeremy Puma, Amazon Catalyst Program and the CoMotion Program at the University of Washington in Seattle for their financial support of the project. Finally, this study has been made possible in part by the US Forest Service Wood Innovation Award (\#FA132237) and by a grant from the USDA Federal State Marketing Improvement Program Award (\#16-FSMIP-WA-0009).

\section{Compliance with ethical standards}

Conflict of interest The authors declare that they have no competing interests.

\section{References}

1. Eastin I, Ganguly I, Sasatani D, Lippke B (2009) The economic contribution of the forest products sector in washington. CINTRAFOR Working paper 116. Seattle

2. Washington (2015) Washington State Department of Revenue. Statistics and reports: gross business income. http://dor.wa.gov/ content/aboutus/statisticsandreports/tid/StatisticsRepor ts.aspx?query=gbinaics. Accessed 13 Sept 2015

3. Washington (2015) Washington State Employment Security Department. Quarterly census of employment and wages. https ://fortress.wa.gov/esd/employmentdata/reports-publications/ industry-reports/quarterly-census-of-employment-and-wages . Accessed 13 Sept 2015

4. National (2016) Forest inventory and analysis. Washington, D.C

5. Sandberg D, Kutnar A (2016) Thermal modified timber (TMT): recent development in Europe and North America. Wood Fiber Sci 48:28-39

6. Yin J, Yuan T, Lu Y, Song K, Li H, Zhao G, Yin Y (2017) Effect of compression combined with steam treatment on the porosity, chemical composition and cellulose crystalline structure of wood cell walls. Carbohydr Polym 155:163-172

7. Hill CA (2007) Wood modification: chemical, thermal and other processes. Wiley, Chischester

8. Esteves BM, Pereira HM (2009) Wood modification by heat treatment: a review. BioResources 4:370-404

9. Kymäläinen M, Mlouka SB, Belt T, Merk V, Liljeström V, Hänninen T, Uimonen T, Kostiainen M, Rautkari L (2018) Chemical, water vapour sorption and ultrastructural analysis of Scots pine wood thermally modified in high-pressure reactor under saturated steam. J Mater Sci 53:3027-3037

10. Čermák $P$, Vahtikari $K$, Rautkari L, Laine $K$, Horáček $P$, Baar J (2016) The effect of wetting cycles on moisture behaviour of thermally modified Scots pine (Pinus sylvestris L.) wood. J Mater Sci 51:1504-1511

11. Boonstra M, Van Acker J, Kegel E, Stevens M (2007) Optimisation of a two-stage heat treatment process: durability aspects. Wood Sci Technol 41:31-57

12. Ayadi N, Lejeune F, Charrier F, Charrier B, Merlin A (2003) Color stability of heat-treated wood during artificial weathering. Holz als Roh-und Werkstoff 61:221-226 
13. Herrera R, Arrese A, de Hoyos-Martinez PL, Labidi J, Llano-Ponte $R$ (2018) Evolution of thermally modified wood properties exposed to natural and artificial weathering and its potential as an element for façades systems. Constr Build Mater 172:233-242

14. Awoyemi L, Jones I (2011) Anatomical explanations for the changes in properties of western red cedar (Thuja plicata) wood during heat treatment. Wood Sci Technol 45:261-267

15. Tjeerdsma B, Militz H (2005) Chemical changes in hydrothermal treated wood: FTIR analysis of combined hydrothermal and dry heat-treated wood. Holz als roh-und Werkstoff 63:102-111

16. Kačíková D, Kačík F, Čabalová I, Ďurkovič J (2013) Effects of thermal treatment on chemical, mechanical and colour traits in Norway spruce wood. Bioresour Technol 144:669-674

17. Jozsa LM, Munro BD, Gordon JR (1998) Basic wood properties of second-growth Western hemlock. Forintek Special Publication No. SP-38. Vancouver, Canada

18. Dou C, Marcondes WF, Djaja JE, Bura R, Gustafson R (2017) Can we use short rotation coppice poplar for sugar based biorefinery feedstock? Bioconversion of 2-year-old poplar grown as short rotation coppice. Biotechnol Biofuels 10:144

19. Technical (2001) TAPPI test methods. Acid-insoluble lignin in wood and pulp, test method T 222 om-11. Atlanta, Georgia

20. Dou C, Ewanick S, Bura R, Gustafson R (2016) Post-treatment mechanical refining as a method to improve overall sugar recovery of steam pretreated hybrid poplar. Bioresour Technol 207:157-165

21. Sluiter A, Hames B, Ruiz R, Scarlata C, Sluiter J, Templeton D (2008) Determination of ash in biomass. Laboratory Analytical Procedure (LAP), Golden

22. Sluiter A, Ruiz R, Scarlata C, Sluiter J, Templeton D (2008) Determination of extractives in biomass. Golden, Colorado

23. Kellogg RM, Wangaard FF (2007) Variation in the cell-wall density of wood. Wood Fiber Sci 1:180-204

24. ISO 13061-1 (2014) Physical and mechanical properties of woodtest methods for small clear wood specimens: Part 1-determination of moisture content for physical and mechanical tests. Geneva, Switzerland

25. Kekkonen PM, Telkki V-V, Jokisaari J (2010) Effect of thermal modification on wood cell structures observed by pulsed-fieldgradient stimulated-echo NMR. J Phys Chem C 114:18693-18697

26. Yin Y, Berglund L, Salmén L (2011) Effect of steam treatment on the properties of wood cell walls. Biomacromol 12:194-202

27. Song K, Yin Y, Salmén L, Xiao F, Jiang X (2014) Changes in the properties of wood cell walls during the transformation from sapwood to heartwood. J Mater Sci 49:1734-1742

28. Guo J, Song K, Salmén L, Yin Y (2015) Changes of wood cell walls in response to hygro-mechanical steam treatment. Carbohydr Polym 115:207-214

29. Song K, Wu Q, Zhang Z, Ren S, Lei T, Negulescu II, Zhang Q (2015) Porous carbon nanofibers from electrospun biomass tar/polyacrylonitrile/silver hybrids as antimicrobial materials. ACS Appl Mater Interfaces 7:15108-15116

30. Mburu F, Dumarçay $S$, Bocquet JF, Petrissans $M$, Gérardin $P$ (2008) Effect of chemical modifications caused by heat treatment on mechanical properties of Grevillea robusta wood. Polym Degrad Stab 93:401-405
31. Esteves B, Graca J, Pereira H (2008) Extractive composition and summative chemical analysis of thermally treated eucalypt wood. Holzforschung 62:344-351

32. Thomas R (1977) Wood: structure and chemical composition. Wood technology: chemical aspects. ACS Publications, Washington, D.C., pp 1-23

33. Severo ETD, Calonego FW, Sansígolo CA, Bond B (2016) Changes in the chemical composition and decay resistance of thermallymodified Hevea brasiliensis wood. PLoS ONE 11:e0151353

34. Patel JP, Xiang ZG, Hsu SL, Schoch AB, Carleen SA, Matsumoto D (2015) Path to achieving molecular dispersion in a dense reactive mixture. J Polym Sci B Polym Phys 53:1519-1526

35. Patel JP, Xiang ZG, Hsu SL, Schoch AB, Carleen SA, Matsumoto $D$ (2017) Characterization of the crosslinking reaction in high performance adhesives. Int J Adhes Adhes 78:256-262

36. Patel JP, Zhao CX, Deshmukh S, Zou GX, Wamuo O, Hsu SL, Schoch AB, Carleen SA, Matsumoto D (2016) An analysis of the role of reactive plasticizers in the crosslinking reactions of a rigid resin. Polymer 107:12-18

37. Navi P, Girardet F (2000) Effects of thermo-hydro-mechanical treatment on the structure and properties of wood. Holzforschung 54:287-293

38. Gunduz G, Aydemir D, Karakas G (2009) The effects of thermal treatment on the mechanical properties of wild Pear (Pyrus elaeagnifolia Pall.) wood and changes in physical properties. Mater Des 30:4391-4395

39. Bakar BFA, Hiziroglu S, Tahir PM (2013) Properties of some thermally modified wood species. Mater Des 43:348-355

40. Antal MJJ, Varhegyi G (1995) Cellulose pyrolysis kinetics: the current state of knowledge. Ind Eng Chem Res 34:703-717

41. Mitsui $K$, Takada H, Sugiyama M, Hasegawa R (2001) Changes in the properties of light-irradiated wood with heat treatment. Part 1. Effect of treatment conditions on the change in color. Holzforschung 55:601-605

42. Chu D, Mu J, Zhang L, Li Y (2017) Promotion effect of NP fire retardant pre-treatment on heat-treated poplar wood. Part 1: color generation, dimensional stability, and fire retardancy. Holzforschung 71:207-215

43. Morita S, Yamazumi T (1987) Coloring of wood by high pressure steam. Coloring degree and appearance of defects depending on treatment condition. Wood Ind 42:26-272

44. Thakur V, Singha A, Thakur M (2012) Biopolymers based green composites: mechanical, thermal and physico-chemical characterization. J Polym Environ 20:412-421

45. Singha A, Thakur VK (2009) Physical, chemical and mechanical properties of Hibiscus sabdariffa fiber/polymer composite. Int J Polym Mater 58:217-228

46. Priya B, Gupta VK, Pathania D, Singha AS (2014) Synthesis, characterization and antibacterial activity of biodegradable starch/ PVA composite films reinforced with cellulosic fibre. Carbohydr Polym 109:171-179

47. Salmen L, Burgert I (2009) Cell wall features with regard to mechanical performance. A review COST Action E35 20042008: wood machining-micromechanics and fracture. Holzforschung 63:121-129 